ACCEPTED MANUSCRIPT, New European Journal of Criminal Law, SAGE (Oct, 20, 2021).

Volume: 12 issue: 4, page(s): 552-574 https://doi.org/10.1177/20322844211060227,

Article first published online: November 11, 2021; Issue published: December 1, 2021

\title{
Radical Men and Sympathizing Women? Gendered Constructions of Agency in Charges of Terrorism in Germany
}

KERSTIN EPPERT*, VIKTORIA ROTH

Corresponding Author: Kerstin Eppert, Institute of Interdisciplinary Conflict and Violence Research, Bielefeld University, Universitätsstraße 25, 33615 Bielefeld, Germany; kerstin.eppert@uni-bielefeld.de

\begin{abstract}
In the past, scholarly research in extremism and terrorism studies tended to analyse women's engagement with violent ideology-based groups from a normative angle, framing female commitment to radical ideologies and violence as cases of inherent victimization or as instigated by a dominant male. Particularly in the negotiation of women's transnational support of terror organizations in Syria, gendered frames of political agency have been reproduced in the institutional practices of the judiciary. Taking the case of Germany and four appeals lodged at the Federal Court of Justice between 2015 and 2017 as examples, this article analyses gendered conceptions of agency in argumentation with respect to criminal liability in the context of extremist engagement in Syria. It identifies, first, the gendered construction of defendants before the courts and inherently gendered assumptions about agency and, second, a formal organizational understanding in the terrorism clauses as the two underlying problems and suggests that current concepts in terrorism norms at national, EU und international levels deflect the focus on the wider conflict dynamics where civilians' support to violence is concerned.
\end{abstract}

Key words: Female agency, ISIS, terrorism norms, gender, criminal law

\section{Authors' note}

The authors would like to thank Denis van de Wetering for a stimulating exchange in the early stages of this paper.

\section{Declaration of conflicting interests}

The authors declared no potential conflicts of interest with respect to the research, authorship, and/or publication of this article.

\section{Funding}

The author(s) received no financial support for the research, authorship, and/or publication of this article.

\section{ORCID iD}

Kerstin Eppert, https://orcid.org/0000-0002-3515-2341

Viktoria Roth https://orcid.org/0000-0003-1323-7384 


\section{Introduction}

In Europe, criminal court cases on charges of terrorism and support for terrorist organizations are on the rise as a consequence of the substantial transnational mobilization and recruitment of foreign supporters by Islamic State (ISIS) and its affiliates. With the military decline of the organization and the return of its civilian supporters to their countries of origin, national courts are now tasked with bringing to justice those citizens who participated in, and committed crimes for, the terror regime. ${ }^{1}$ In the case of Germany, until 2017, the Federal Prosecutor General (GBA) predominantly dealt with young men who had been recruited by Islamist groups and travelled to Syria or Northern Iraq to join terrorist organizations as combatants or to provide logistical support and medical care. Since 2017, however, public prosecution in Germany increasingly seeks to indict female supporters and recruits. ${ }^{2}$ This is due, in part, to evolving knowledge and acknowledgement of the role of women in terrorist organizations and support networks on the part of legal agencies, as well as to the substantial number of female returnees from Syria and Iraq.

In contrast to cases involving male defendants, earlier trials involving female defendants were marked by a procedural recourse in the form of appeals to the Federal Court of Justice (BGH), that aim at the judicial review of the applicability of terrorism clauses to acts of support performed by female offenders. Between 2015 and 2018, four appeals of this kind were lodged before the BGH contesting the legal assessment of complicity and perpetratorship in the context of terrorist activities. While these appeals appear to relate mainly to substantial questions of German criminal law (StGB), analysis shows that a more complex problem has to be considered here too. This concerns gendered assumptions of human agency inherent to the law and gendered contexts of transnational engagement in the ideological project of ISIS. The cases illustrate that, in regard to criminal law, tension arises from the application of state-centred legal norms of terrorism to the current dynamics of transnational mobilization, on the one hand, and the recruitment and deployment of men and women to ISIS-territories, on the other hand. In particular, acts relating to charges of 'preparation of a state-threatening act of violence' ( $\$ 89 \mathrm{a}$ StGB), and 'support to' and 'membership of' terrorist organizations ( $\$ 129 a, b$ StGB), emerge as central but contentious norms in the court appeals. All norms of StGB discussed here were integrated into national legislation in response to requirements of EU legal frameworks. ${ }^{3}$ The

\footnotetext{
${ }^{1}$ Christophe Paulussen and Eva Entenmann, ‘Addressing Europe's Foreign Fighter Issue' [2014] 25 Secur. Hum. Rights 86; Sharon Weill, 'French foreign fighters: The engagement of administrative and criminal justice in France' [2018] 100 Int. Rev. Red Cross 211; Alexander Murray, 'Terrorist or Armed Opposition Group Fighter? The Experience of UK Courts and the Implications for Public International Law' [2018] 20 Int. Community Law Rev. 281; Sharon Weill, 'Transnational Jihadism and the Role of Criminal Judges: An Ethnography of French Courts' [2020] 47 J. Law Soc.

${ }^{2}$ Data from GBA press releases (Cases involving female defendants; 2014 (3), 2016 (1), 2018 (1), 2019 (11), 2020 (7), see <https://www.generalbundesanwalt.de/DE/Presse/Archiv/archiv_node.html>.

3 For full text on §89a StGB, see <https://dejure.org/gesetze/StGB/89a.html>; for §129a and b <https://dejure.org/gesetze/StGB/129a.html> and <https://dejure.org/gesetze/StGB/129b.html>. All translations of legal texts were carried out by the authors, citations of laws are cut to essentials as relevant to the argument. Directive (EU) 2017/541 of the European Parliament and of the Council of 15 March 2017 on combating terrorism and replacing Council Framework Decision 2002/475/JHA and amending Council Decision 2005/671/JHA [2017] OJ L88/6, art. 8-12, 15 and 16 provide the equivalent norms, particularly "serious crimes... that aim...to seriously
} 
discussion of the cases intimates that, with regard to national law, the questions of 'What actions threatens the state'? and 'What constitutes support to or membership of' in a terrorist organization? may need to be reevaluated against the context of the wider conflict in Syria and Iraq. More particularly, we suggest that, when looked at from the perspective of current terrorism legislation at EU and domestic levels, the wider effects of civilians' transnational support to organized violence in Syria escape domestic and international monitoring, preventative and retributive actions and that this has to do with gendered conceptions in criminal law.

In regard to the integration of lessons learnt from Syria and EU efforts of legal harmonization for effective prevention and prosecution of criminal engagement and terrorism ${ }^{4}$, the underlying issues discussed from the domestic perspective are of relevance to deliberations and legal development at EU and UN levels as well. This concerns, in particular, international efforts to develop comprehensive and harmonised frameworks of action carrying operational definitions of terrorist acts and preparatory actions. ${ }^{5}$

The article establishes a comparative analysis of the four appeals and contextualizes the argumentation of BGH in the respective cases from a socio-legal perspective within current scholarship of gender and agency in transnational jihadism. ${ }^{6}$ The discussion contributes to critical scholarship on gender in socio-legal studies, justice and criminal law in the dealing with transnational civilian engagement in terrorism. ${ }^{7}$ The first part discusses the ambivalence of gender and agency in current scholarship of transnational jihadism and introduces Emirbayer and Mische's ${ }^{8}$ relational definition of agency as a point of departure for the discussion of the presented cases and then presents gendered constructions of agency in the political ideology of ISIS. The second part reconstructs and compares socio-legal assessments of male and female support to extremist violence and Islamist terrorism as evidenced in the four decisions of the BGH. It extrapolates the implicitly gendered understanding of agency in German and concurrent European terrorism norms and demonstrates where the interplay of gendered

intimidate a population, to unduly compel a government... to perform or to abstain from performing any act, or to seriously destabilise or destroy the fundamental political, constitutional, economic or social structures of a country" (ibid. art. 8).

${ }^{4}$ Council Framework Decision 2008/841/JHA on the fight against organised crime OJ L 300/42 (2008); Council Framework Decision 2008/919/JHA of 28 November 2008 amending Framework Decision 2002/475/JHA on combating terrorism OJ L 330/21 (2008); Directive (EU) 2017/541 (n 3).

${ }^{5}$ Directive (EU) 2017/541 (n 3).

${ }^{6}$ Jessica Auchter, 'Gendering Terror, Discourses of Terrorism and Writing Woman-as-Agent' [2012] 14 Int. Fem. J Polit. 121; Nelly Lahoud, 'Can Women Be Soldiers of the Islamic State?' [2017] 59 Survival 61; Meredith Loken and Anna Zelenz, 'Explaining extremism: Western women in Daesh' [2018] 3 Eur. J. of Int. Secur. 45; Nelly Lahoud, Empowerment or subjugation: An analysis of ISIL's gendered messaging (2018) UN WOMEN; Mia Bloom and Ayse Lokmanoglu, 'From Pawn to Knights: The Changing Role of Women's Agency in Terrorism?' [2020] Stud. Confl. Terror. 1.

${ }^{7}$ Dara Conduit and Ben Rich, 'Foreign Fighters, Human Rights and Self-Determination in Syria and Iraq: Decoding the Humanitarian Impact of Foreign Fighters in Practice' [2016] 18 Int. Community Law Rev. 431; Weill (n 1); Brittnee Carter, 'Bringing suspected terrorists to justice? Revealing bias against Muslims in applied counter terrorism by the U.S' [2020] 23 Contemp. Justice Rev. 444.

${ }^{8}$ Mustafa Emirbayer and Ann Mische, 'What Is Agency?' [1998] 103 Am. J. Sociol. 962. 
ideology and criminal law produce specific subject positions of the defendants in regard to their practical engagement within ISIS's transnational support networks.

The article concludes with a critical reflection on the underlying normative controversies that the courts dealt with, problematizing the gendered assessment of civilian engagement in the context of ISIS and its politico-territorial project of a caliphate. It argues that the ideological foundation that attracts and stabilizes the constituency-in-the-making, also legitimizes a deeply gendered social order that frames human agency, which in turn substantially fuels conflict dynamics.

\section{Analysing Agency and Agentic Orientation in women's support to extremist violence and Islamist terrorism}

On March 22, 2018, a decision by the BGH in the case of a German female ISIS supporter made headlines in the national news. ${ }^{9}$ Following an appeal by the GBA, the court reiterated a previous instance's decision not to issue an arrest warrant against the accused on grounds of suspected membership of a foreign terrorist organization ( $\$ 129 a, b$ StGB) for lack of evidence. The accused had travelled from Germany to Iraq jointly with her spouse to join ISIS in March 2016 and had subsequently spent a year and a half on ISIS territory, where her spouse received family allocations from the organization for his work as a nurse and the accused was left in charge of organizing their family life. The reasoning of the court emphasized that there were insufficient legal grounds for an arrest since there was neither proof of her formal membership of the organization of ISIS, nor of her participation in membership-related activities.

The ruling triggered our interest in the case, as it concerned the negotiation of the political nature of women's engagement and their agency as members or supporters of violent organizations. The issue of criminal liability of foreign civilian supporters of terror organizations in Syria and Iraq, and here particularly female supporters, is part of academic debate in Germany ${ }^{10}$ that also encompasses critical analysis of normative changes in German terrorism law in the fight against terror and security policy. ${ }^{11}$ At the centre of the debate stands the question whether female foreign civilians' presence and participation in the everyday life

\footnotetext{
9 BGH, 22.03.2018 StB 32/17

10 Lasse Gundelach, 'Ehefrauen von IS-Kämpfern in der Rechtsprechung des BGH, Mitgliedschaft oder Unterstützung einer ausländischen terroristischen Vereinigung durch Leben im Kalifat?' [2019] 20 HRRS <http://www.hrr-strafrecht.de>; Markus Bohn and Jason Coombe, IS-Rückkehrerinnen-Fall. Der Fall des Monats im Strafrecht (2019) <www.fall-des-monats.de>; Lasse Gundelach, 'Alltagsleben von IS-Anhängerinnen als Unterstützungshandlung' [2020] StV 170.

${ }^{11}$ Mark A Zöller, 'Zehn Jahre 11. September - Zehn Jahre Gesetzgebung zum materiellen Terrorismusstrafrecht in Deutschland' [2012] StV 364; Jens Puschke and Jannik Rienhoff, 'Terrorismusbekämpfung durch das Strafrecht' in Jens Puschke and Tobias Singelnstein (eds), Der Staat und die Sicherheitsgesellschaft (Springer Fachmedien Wiesbaden, Wiesbaden 2018); Jens Puschke, 'Das neue Terrorismusstrafrecht im Lichte der Verfassung' [2018] Kriminalpolitische Zeitschrift (KriPoZ) 101; Beatrice Brunhöber, 'Funktionswandel des Strafrechts in der Sicherheitsgesellschaft' in Jens Puschke and Tobias Singelnstein (eds.), Der Staat und die Sicherheitsgesellschaft (Springer Fachmedien Wiesbaden, Wiesbaden 2018).
} 
within the voluntary act of submitting to ISIS control constitutes an act of support to the organization. Beyond its implications for a critical discussion of gendering in terrorism laws, this debate is of international relevance as it concerns the impact of foreign civilian support in conflicts such as in Syria and Iraq more generally. These conflict dynamics still need to be fully understood and processed and, eventually, also be regulated through international monitoring and intervention structures. Current scholarly research and our own data suggest that the role of women in the implementation of the politico-territorial project of a caliphate, their support for it and their determination to participate in bringing it to life through everyday practices in the occupied territories constitute relevant resources for producing social reality. ${ }^{12}$ Moreover, in the context of the proclamation of a caliphate in June 2014 and the appeal to Muslims worldwide to join this 'home territory', the ensuing support of a self-proclaimed 'transnational active constituency' constitutes a practice of recognition and submission to the laws and practices of the 'state-in-the-making' that is rather unprecedented in its scope and impact where ISIS is concerned. ${ }^{13}$ The scholarly focus on the religious-ideological dimension of the jihadist mobilization hides another, possibly more important dynamic, which is that this organization successfully encouraged a force of multinational men and women to migrate and build a "state" 14 , thereby obscuring "the fundamental contemporary features" 15 of the project. While the role of foreign fighters in Syria is starting to be addressed in scholarly research ${ }^{16}$, the impact of foreign civilians on the conflict in Syria remains yet to be explored. The trans-local organization of violence, however, is widely explored, with empirical data stemming, inter alia, from social media evidence and testimony of ISIS supporters in legal trials ${ }^{17}$ or survivors' accounts that help understand the systematic of violence and oppression. ${ }^{18}$

Scholarship critically engages with the binary construction of women in the context of political violence and particularly in terrorism research as either apolitical and legally irrelevant bystanders or victims, whose decisions and actions are guided or dominated by male relatives or

\footnotetext{
${ }^{12}$ Hamoon Khelghat-Doost, 'Women of the Caliphate: the Mechanism for Women's Incorporation into the Islamic State (IS)' [2017] 11 Perspect. Terror.; Hamoon Khelghat-Doost, 'The Strategic Logic of Women in Jihadi Organizations' [2019] 42 Stud. Confl. Terror. 853.

${ }^{13}$ Joana Cook and Gina Vale, From Daesh to 'Diaspora': Tracing the Women and Minors of Islamic State (London 2018).

${ }^{14}$ Nadia Al-Dayel, 'Sexual Suppression and Political Agency: Evoking a Woman's Support for the Islamic State' [2018] 44 Stud. Confl. Terror. Online first 2.

${ }^{15}$ Ibid.

${ }^{16}$ Ben Rich and Dara Conduit, 'The Impact of Jihadist Foreign Fighters on Indigenous Secular-Nationalist Causes: Contrasting Chechnya and Syria’ [2015] 38 Stud. Confl. Terror. 113.

${ }^{17}$ Sarah Klosterkamp and Paul Reuber, "„Im Namen der Sicherheit“ - Staatsschutzprozesse als Orte politischgeographischer Forschung, dargestellt an Beispielen aus Gerichtsverfahren gegen Kämpfer und UnterstützerInnen der Terrororganisation „Islamischer Staat“' [2017] 72 Geogr. Helv. 255; Tasniem Anwar, 'Unfolding the Past, Proving the Present: Social Media Evidence in Terrorism Finance Court Cases' [2020] 14 Int. Pol. Sociol. 382; Sarah Klosterkamp, "'Security, mobility, and the body - Syrian insurgent groups' infrastructures and their geopolitical contestations through/by/in legal institutions"” [2021] 84 Pol. Geogr. 102301.

${ }_{18}$ Nadia Al-Dayel, Andrew Mumford and Kevin Bales, 'Not Yet Dead: The Establishment and Regulation of Slavery by the Islamic State’ [2020] Stud. Confl. Terror.
} 
partners or pathological individuals, for example, in the establishment of criminal liability ${ }^{19}$ or in the media and public discourses. ${ }^{20}$ Both their active engagement in political conflict and their strategic relevance for militant organizations are misrecognized and too little explored empirically. ${ }^{21}$ Against this context, the overarching question that our argument engages with is a double one: it asks first whether the complexity of the context and the political nature of women's support to and association with militant jihadism is recognized in legal cases involving charges of terrorism in Germany. Second it asks if the relevant legal norms of StGB produce gender bias through their inherent assumptions on the organization and agentic orientation of violence and terror.

\section{Capturing gendered agency in scholarship}

Women's agency is widely discussed in terrorism and radicalization research. A review of scholarship on gender and agency in the field of terrorism and violence reveals a recourse to different definitions of the concept, advancing agency, for example, as economic or political empowerment ${ }^{22}$, others bringing an action theoretical or rational choice perspective into the discussion, or critical-feminist approaches. ${ }^{23}$ In regard to their empirical focus, scholarly contributions predominantly concentrate on constructions of female agency as it is portrayed in Jihadist propaganda materials ${ }^{24}$ as well as on analyses of social media or other online accounts of women activists of Jihadist organisations. While the former allow for the macro-structural analysis of female political participation, the latter provide micro-sociological insights into (the staging of) the activists' lives and everyday practices which may then be juxtaposed to the macro-structural traits of engagement. ${ }^{25}$.

Hitherto, much of the scholarly literature on women in Islamist groups and organizations focuses on the victimization, depoliticization and marginalization of females within maledominated structures. Emphasising women's (lack of) agency as socio-religious construction based on Islamic beliefs, particularly feminist analyses reproduce a dichotomous social

\footnotetext{
${ }^{19}$ Audrey Alexander and Rebecca Turkington, 'Treatment of Terrorists: How Does Gender Afect Justice?' (2018) 11 CTC Sentinel 24.

${ }^{20}$ Brigitte L Nacos, 'The Portrayal of Female Terrorists in the Media: Similar Framing Patterns in the News Coverage of Women in Politics and in Terrorism' [2005] 28 Stud. Confl. Terror. 435; Caron E Gentry and Laura Sjoberg, Beyond mothers, monsters, whores. Thinking about women's violence in global politics (Zed Books, London 2015); Michaela Köttig, 'Gender Stereotypes Constructed by the Media: The Case of the National Socialist Underground (NSU) in Germany’ in Michaela Köttig, Renate Bitzan and Andrea Petö (eds), Gender and Far Right Politics in Europe (Springer International Publishing, Cham 2017); Alice Martini, 'Making women terrorists into "Jihadi brides": an analysis of media narratives on women joining ISIS' [2018] 11 Crit. Stud. Terror. 458.

${ }^{21}$ Lauren Vogel, Louise Porter and Mark Kebbell, 'The Roles of Women in Contemporary Political and Revolutionary Conflict: A Thematic Model' [2014] 37 Stud. Confl. Terror. 91; Shelli Israelsen, 'Why Now? Timing Rebel Recruitment of Female Combatants' [2020] 43 Stud. Confl. Terror. 123.

${ }^{22}$ Lahoud (n 5).

${ }^{23}$ Auchter (n 5).

${ }^{24}$ Naila Kabeer, 'Resources, Agency, Achievements: Reflections on the Measurement of Women's Empowerment' [1999] 30 Dev. Change 435; Lahoud (n 5); Bloom and Lokmanoglu (n 5).

${ }^{25}$ Loken and Zelenz (n 5).
} 
geography with a (male) public sphere and a (female) private sphere. ${ }^{26}$ The use of such a gendered public-private dichotomy is problematic as it reproduces inherent claims on hegemonic social and political structures and perpetuates narratives of powerlessness and lack of agency in women. ${ }^{27}$ Along similar lines, international research on female terrorism has tended in the past to neglect the independently motivated decisions of (young) women to engage in political violence by primarily focusing on personal reasons like revenge, rape, recovery, relationship or romance as driving forces of radicalization. While recent empirical studies have shown that women and men are driven to radical groups for similar reasons-which include a combination of political, social, economic, ideological and personal motives - there is a persistence to define men's motivations as rational and autonomous, while describing women's as emotionally driven and manipulated. ${ }^{28}$ In the case of researching Muslim women, the perpetuation of gender stereotypes in scholarly work on women and political violence is further compounded by neo-orientalist frames and neo-colonial constructions of knowledge. ${ }^{29}$

In the context of Islamic State, analysis of female agency needs to acknowledge the heterogeneity of groups of female activists who engage with the organisation, their diverse socio-cultural backgrounds and the geographical context within which they engage, that is, agency's relational constitution. In current scholarly literature, these empirical differences tend to be neglected particularly where analysis is solely grounded in data of ideological texts and propaganda, suggesting a degree of homogeneity within the larger group of women activists group that does not hold true empirically.

Amongst others, Bloom and Lokmanoglu ${ }^{30}$ criticize the conceptualization of agency as genderneutral in Terrorism studies and International Relations and suggest to bring in the feminist lens for a better understanding of the scope and political nature of women's engagement. We argue that aiming at a universal attribution of one distinct form of female agency is unhelpful in these contexts in light of the rather diverse possibilities of engaging with terrorist organizations. Empirical studies confirm that, for one, the process of engaging with and supporting terrorist organizations more generally and, the transnational recruitment and mobilization of civilians by ISIS more particularly is multi-faceted and complex. Agentic orientation and frames of action may evolve differently for different modes of engagement depending on, for example, whether a person travels to ISIS-controlled territories or engages in home-based support. Consequently, analysis of agency needs to be situated within the specific socio-relational

\footnotetext{
${ }^{26}$ Jean B Elshtain, Public man, private woman: Women in social and political thought (2. ed. Princeton Univ. Press, Princeton, NJ 1993); Auchter (n 5).

${ }^{27}$ Diane Singerman, 'Where Has All the Power Gone? Women and Politics in Popular Quarters of Cairo' in Fatma M Göçek and Shiva Balaghi (eds), Reconstructing Gender in the Middle East: Tradition, Identity, and Power (Columbia University Press, New York, NY 1995) 180.

${ }^{28}$ Karla J Cunningham, 'Cross-Regional Trends in Female Terrorism' [2003] 26 Stud. Confl. Terror. 171; Anne Speckhard, 'Female Suicide Bombers in Iraq' [2009] 5 Democr. Secur. 19; Mia Bloom, 'Bombshells: Women and Terror' [2011] 28 Gender Issues 1.

${ }^{29}$ Martini (n 19); Abdul H Azeez, 'Brides vs fighters in the media lens: Orientalism, Islamophobia and gender in media discourse on international recruits to ISIS' [2019] 12 J. Arab Muslim Media Res. 115.

${ }^{30}$ Bloom and Lokmanoglu (n 5).
} 
context and disaggregated according to the respective phases and dimensions of engagement to allow for a differentiated analysis of its conditions.

\section{Concepts of female jihad}

Women fighting in jihad remain a highly controversial issue in classical Salafi scholarship and contemporary Islamic legal literature as well as in radical interpretations advanced by terrorist groups and organizations. Concerning militant jihad, legal Islamic sources essentially exclude women from armed struggle, with very few exceptions. ${ }^{31} \mathrm{Jihad}$, as a core concept of Islam and a fundamental ethical basis of Muslim belief and practice, has been interpreted in various ways throughout Islamic history. ${ }^{32}$ Modern jihadi-Salafist organizations and groups refer primarily to the militant form of jihad. The strategic abuse of the concept for terrorist purposes serves as an important resource to indoctrinate, recruit and mobilize men and women all over the world, to legitimate their global agenda and tactics as well as to justify serious acts of violence against humans and facilities to enforce their objective of gaining political power. ${ }^{33}$ In the course of the history of terrorist organizations multiple violence-oriented narratives and action scripts have been aligned with ideological frames that are reproduced in acts of violence and documented in claims of responsibility or mobilization calls. Many groups and individuals have taken on aspects of the global jihadist ideology without necessarily entering into the command-andcontrol structure of ISIS or other organizations ${ }^{34}$ - a development that has been taken into account by the definition of intentional acts and aims in an EU Council Framework Decisions (CFD) 2008/841 and 2008/919 35 and in German criminal law since 2009.

In its propaganda, ISIS locates women's primary roles-and thus their agentic field-in the private sphere within the family structure. As mothers, sisters, daughters, and wives of martyrs, which carries expectations of social and psychological support, too, but not, however, as genuinely active combatants. To the extent that the role of female fighters is covered in the organization's propaganda, on the one hand, it discourages female readers from taking on male duties more generally, while, on the other hand, glorifying historical and contemporary exceptions of female fighters and martyrs. Narratives of female martyrs are also leveraged to convey messages of emasculation to discredit, humiliate and shame male audiences. ${ }^{36}$ In ISIS' propaganda, the ideal-typical Muslim woman is constructed as a strong individual in every possible role: the life-giving mother, authoritative wife and guardian of ideology. ${ }^{37}$ In this

\footnotetext{
${ }^{31}$ David Cook, 'Women Fighting in Jihad?' [2005] 28 Stud. Confl. Terror. 375379.

${ }^{32}$ John L Esposito, Unholy war: Terror in the name of Islam (Oxford Univ. Press, Oxford 2003).

${ }^{33}$ Tengku E Ramlan and Hakim Nurul, 'The Concept of Jihad in Islam’ [2016] 21 Int. J. Humanit. Soc. Sci. 35.

${ }^{34}$ Anne Speckhard, 'The New Global Jihad, 9-11 and the Use of Weapons of Mass Destruction' [2006] 2 Democr. Secur. 287.

35 (N 4).

${ }^{36}$ Andrea S Aasgaard, '"Migrants, Housewives, Warriors or Sex Slaves: AQ's and the Islamic State's Perspectives on Women.’ [2017] 16 Connections Q. J. 99.

${ }^{37}$ Katharina von Knop, 'The Female Jihad: Al Qaeda's Women' [2007] 30 Stud. Confl. Terror. 397; Sara J Jacobsen, "Mother", "martyr wife" or "mujahida": the Muslim woman in Danish online jihadi Salafism. A study
} 
regard, she is also considered an actor in her own right and a necessary part of ideological narratives.

\section{Women in the Caliphate and its transnational networks}

The participation of women in the implementation of the ideology thus reaches substantially beyond their coincidental presence in ISIS-controlled territories. "One of the Islamic State's explicit goals is to attract citizens, and the specific aim of a female authored column [N.B. in its propaganda outlet Dabiq] is to attract women. In order to be effective, recruitment narratives must persuade a breakage of a social contract between the citizen and her state" 38 . Migration to ISIS territories thus constitutes a contribution to putting the societal ideal into practice in which women partake as active agents. According to scholarly literature and empirical data, one of the central criteria that secured the initial success of ISIS and helped it move beyond a mere militant entity was its state project. ${ }^{39}$

Women held an essential role in the successful implementation and legitimization of the Caliphate, with gender-segregated healthcare, education, service provision, finance, military, and police services. Evidence suggests that these segregated institutions enabled a selected group of women to access public functions and thereby exercise a relatively high degree of agency within their assigned roles, for example, as doctors, nurses, teachers, tax collectors or moral police in the all-female al-Khansaa Brigade..$^{40}$ Empirical research on the engagement of 'Western' women in terrorism and, more specifically, studies addressing these females within organizational structures of ISIS still remain limited. Recent empirical studies on terrorism point to the diverse roles played by women in terrorist groups and organizations, including as recruiters, propagandists, ideologues, supporters, facilitators and perpetrators of violence. ${ }^{41}$ Various authors point out that girls and (young) women provide a fundamental contribution to maintaining and disseminating extreme Islamist ideologies with their increasing differentiation, networking and professionalization in extremist online and offline networks. ${ }^{42}$

Women's engagement with ISIS therefore needs to be analysed and evaluated in the context of the ideology and the relational formations it opens up in different contexts - from the decision to migrate through practised citizenship in the state-to-be and, eventually, the return to their home countries. Our data confirm that female engagement in transnational Islamist networks in

\footnotetext{
of the assigned role of the Muslim woman in online jihadi communication' (2016) 10 TIFO 165; Katharina Kneip, 'Female Jihad - Women in the ISIS' [2016] 29 Politikon 88.

38 Al-Dayel (n 13) 4.

${ }^{39}$ Khelghat-Doost (n 11); Hamoon Khelghat-Doost, The Strategic Logic of Women in Jihadi Organizations: From Operation to State Building (Springer, 2021).

${ }^{40}$ Khelghat-Doost (n 11).

${ }^{41}$ Rebecca Turkington and Agathe Christien, 'Women, Deradicalization, and Rehabilitation: Lessons from an Expert Workshop' (2018) Georgetown Institute for Women, Peace and Security (GIWPS) <https://giwps.georgetown.edu/resource/women-deradicalization>.

${ }^{42}$ Carolyn Hoyle, Alexandra Bradford and Ross Frenett, Becoming Mulan? Female Western Migrants to ISIS (Institute for Strategic Dialogue, London 2015)
} 
Germany and Syria is thoroughly organized and coordinated on the basis of the above functional roles. Despite their informality, these networks are structured and oriented towards organizational purposes and complement operations carried out by male supporters.

\section{A relational concept of agency}

Agency, so our argument goes, therefore needs to be analysed as a multi-dimensional construct to take into account the diverse, time-sensitive and socio-relational options of participation and engagement in jihadist organizations in Syria and Iraq. Such a multi-dimensional and relational concept of agency is also developed by Emirbayer and Mische ${ }^{43}$, who underline that agency evolves in time ${ }^{44}$, and is established in social processes of 'interaction and communication" 45 which makes it intersubjective. The constitutive elements of agency-its building blocks, so to speak - are 'iteration, projectivity, and practical evaluation' ${ }^{\prime 6}$. These building blocks may vary in their respective sizes in any situation, but all shape 'agency' in their interaction: connecting the instrumental use of practices and habitus (iteration) to pursue an imagined objective or future (projection) and requiring an individual to make practical and normative judgements in the course of his or her decisions (practical evaluation). In the context of ISIS, the building blocks of agency are structured in particular by political ideology of Jihadism and its inherent gender and power relations, and empirically established by social actors - men and womenwho engage with the organization and its state project in one way or the other. This may include, for example, transnational engagement through services online (e.g., translation and dissemination of propaganda), local activism in any country outside ISIS-territories (e.g., fundraising and collection of donations in kind), or personal relocation to ISIS-territories.

Analysis of gender and agency thus needs to consider the situational, relational and temporal context and establish the constitutive elements in the setting of social action.

The analysis of gendered constructions of agency in terrorism norms opens up a wider field of female engagement with ISIS and within its territory. In order to understand women's roles in ensuring the growth, functioning and survival of the organization and its politico-social project, the legal assessment of female engagement needs to be recontextualized from the perspective of the organization's politico-religious and territorial practices and ideology.

\section{Comparison of cases}

The following sections present and discuss the cases and decisions of the courts. Table 1 provides a summary overview of the key data of each case. The empirical analysis comprises of a qualitative content analysis of all four decisions and proceeded in two steps: firstly, the

\footnotetext{
43 (N 7).

${ }^{44}$ Ibid, 963.

${ }^{45}$ Ibid, 973

${ }^{46}$ Ibid, 971.
} 
ACCEPTED MANUSCRIPT, New European Journal of Criminal Law, SAGE (Oct, 20, 2021).

Volume: 12 issue: 4,page(s): 552-574 https://doi.org/10.1177/20322844211060227,

Article first published online: November 11, 2021; Issue published: December 1, 2021

argumentative structures from all four cases were compared. Secondly, the cases were split in two sets according to charges and then coded along thematic clusters, including, for example, descriptions of offences, charges and the legal ontology of laws, role attributes, relational statements, (self-)descriptions of the political and personal motivations of the defendants, behavioural attributes, or specifics on the migration to Syria. In this way, it is possible to compare, from a socio-legal perspective, the case-specific situational, relational and temporal contexts and establish the constitutive elements of social action, or, in other words, the agency of the respective defendants. 
ACCEPTED MANUSCRIPT, New European Journal of Criminal Law, SAGE (Oct, 20, 2021).

Volume: 12 issue: 4,page(s): 552-574 https://doi.org/10.1177/20322844211060227, Article first published online: November 11, 2021; Issue published: December 1, 2021

Table 1. Overview of court cases.

\begin{tabular}{|c|c|c|c|c|}
\hline & \multicolumn{2}{|c|}{$\begin{array}{l}\text { 'State-threatening act of violence' } \\
\text { (\$89a StGB) }\end{array}$} & \multicolumn{2}{|c|}{$\begin{array}{c}\text { 'Membership of/support to terrorist } \\
\text { organization' }(\$ 129 a, \text { b StGB) }\end{array}$} \\
\hline $\begin{array}{l}\text { Cases/ } \\
\text { Gender }\end{array}$ & Case 1 - Female & Case 2 - Male & $\begin{array}{l}\text { Case } 3 \text { - Two females } \\
\text { (relatives to one male) }\end{array}$ & $\begin{array}{l}\text { Case } 4 \text { - Female } \\
\text { (relative to one male) }\end{array}$ \\
\hline Timeline & Jan.-May 2014 & $\begin{array}{l}\text { June } 24-26, \text { Oct.10, } \\
2015\end{array}$ & Nov. 2013-Jan. 2014 & $\begin{array}{l}\text { March 2016-Aug. } \\
2017\end{array}$ \\
\hline Summary & $\begin{array}{l}\text { Migration to SYR with } \\
\text { two daughters ( } 3 \text { and } 6 \\
\text { yrs); Remarried to } \\
\text { JAN/ AQ-combatant; } \\
\text { Approx. five-month } \\
\text { stay in SYR; Instructed } \\
\text { in handling weapons of } \\
\text { war by spouse } \\
\text { (machine pistol, AK- } \\
\text { 47, hand grenades); } \\
\text { Access to hand } \\
\text { grenades in family; } \\
\text { Return to GER due to } \\
\text { deteriorating security } \\
\text { situation. }\end{array}$ & $\begin{array}{l}\text { Two failed attempts to } \\
\text { migrate to SYR; } \\
\text { Intention to join armed } \\
\text { struggle of JAN or } \\
\text { affiliates; Arrested at } \\
\text { Munich Airport: } \\
\text { confiscation of one- } \\
\text { way ticket to Adana, } \\
\text { Turkey, valuable } \\
\text { outdoor clothing, two } \\
\text { cell phones, } € 270 \text { in } \\
\text { cash. }\end{array}$ & $\begin{array}{l}\text { Sister (O.) and female } \\
\text { friend (S.) of a jihadi } \\
\text { combatant (P.) in SYR } \\
\text { (JAS) provided } \\
\text { monetary (cash amount } \\
\text { of } € 275 \text { ) and material } \\
\text { resources (clothes, food } \\
\text { and deodorant); O. } \\
\text { travelled to SYR to } \\
\text { hand these over to her } \\
\text { brother. }\end{array}$ & $\begin{array}{l}\text { Migration of H. to } \\
\text { SYR/IRQ with her } \\
\text { spouse B., B. works as } \\
\text { a nurse, H. is in charge } \\
\text { of household and child } \\
\text { rearing; ISIS payment } \\
\text { of salary and family } \\
\text { allowances to male } \\
\text { spouse. }\end{array}$ \\
\hline $\begin{array}{l}\text { Charges as } \\
\text { per } \\
\text { indictment } \\
\text { (StGB) }\end{array}$ & $\begin{array}{l}\text { Preparation of a state- } \\
\text { threatening act of } \\
\text { violence ( } \$ 89 \text { a (1) } 2) ; \\
\text { Child abduction in two } \\
\text { cases ( } \$ 253(2) 1) ; \\
\text { Convicted in } 1 \text { st } \\
\text { instance and sentenced } \\
\text { to } 18 \text { months' } \\
\text { probation. }\end{array}$ & $\begin{array}{l}\text { 1. Preparation of a } \\
\text { state-threatening act of } \\
\text { violence }(\$ 89 a \text { ( } 1) \text { and } \\
\text { (2) } 1, \text { sec. } 2 a) \text {. }\end{array}$ & $\begin{array}{l}\text { 1. Support to a } \\
\text { (foreign) terrorist } \\
\text { organization }(\S 129 \mathrm{a}(1) \\
1,(5) 1 ; \S 129 \mathrm{~b}(1) 1- \\
3) \text {; } \\
\text { 2. Constitution of co- } \\
\text { perpetratorship ( } \S 25 \\
(2) \text {. }\end{array}$ & $\begin{array}{l}\text { 1. Membership of a } \\
\text { (foreign) terrorist } \\
\text { organization and } \\
\text { membership-related } \\
\text { activities }(\$ 129 \mathrm{a}(1) \text {; } \\
\S 129 \mathrm{~b}(1) 1,2) \text {. }\end{array}$ \\
\hline $\begin{array}{l}\text { Decisions } \\
\text { of } \mathrm{BGH}\end{array}$ & $\begin{array}{l}\text { 1. Appeal of GBA } \\
\text { rejected. }\end{array}$ & $\begin{array}{l}\text { 1. Convicted as } \\
\text { charged }\end{array}$ & $\begin{array}{l}\text { 1.-3. Refusal to open } \\
\text { main proceedings } \\
\text { maintained. }\end{array}$ & $\begin{array}{l}\text { 1. Motion for an arrest } \\
\text { warrant rejected for } \\
\text { female accused. }\end{array}$ \\
\hline $\begin{array}{l}\text { Justifi- } \\
\text { cation }\end{array}$ & $\begin{array}{l}\text { Insufficient evidence of } \\
\text { substantial threat to the } \\
\text { Syrian state through the } \\
\text { defendant. }\end{array}$ & $\begin{array}{l}\text { Planned to join training } \\
\text { camp with the intent of } \\
\text { fighting the Syrian } \\
\text { state reflects the } \\
\text { essence of charges } \\
\text { under } \$ 89 a\end{array}$ & $\begin{array}{l}\text { Insufficient evidence; } \\
\text { items provided were of } \\
\text { no benefit to the } \\
\text { supported member or } \\
\text { the terrorist } \\
\text { organization; }\end{array}$ & $\begin{array}{l}\text { Insufficient evidence; } \\
\text { sojourning on ISIS } \\
\text { territory does not } \\
\text { equate to membership } \\
\text { of the organization; } \\
\text { enacting ISIS politics } \\
\text { through child rearing } \\
\text { does not equate to } \\
\text { organizational support; } \\
\text { ISIS family allowances } \\
\text { paid to the defendant's } \\
\text { spouse. }\end{array}$ \\
\hline $\begin{array}{l}\text { Final } \\
\text { penalty }\end{array}$ & $\begin{array}{l}18 \text { months' probation } \\
\text { for child abduction in } \\
\text { two cases. }\end{array}$ & $2.5 \mathrm{yrs}$ of prison. & Charges dropped. & $\begin{array}{lrr}\text { Request } & \text { for } & \text { arrest } \\
\text { warrant } & & \text { initially } \\
\text { dropped. } & & \end{array}$ \\
\hline
\end{tabular}


ACCEPTED MANUSCRIPT, New European Journal of Criminal Law, SAGE (Oct, 20, 2021).

Volume: 12 issue: 4, page(s): 552-574 https://doi.org/10.1177/20322844211060227,

Article first published online: November 11, 2021; Issue published: December 1, 2021

\begin{tabular}{|l|l|l|l|l|}
\hline Case file & BGH, 27. October 2015 & BGH, 06. April 2017 3 & BGH, 14. December \\
& 3StR 218/15 & BGH, 22. March 2017 \\
StR 326/16
\end{tabular}

A brief reference needs to be made here on the interrelation of EU legal provisions on terrorism and German criminal law. The legal norms of StGB structuring the analysis in the following sections, i.e. $\$ \S 89 \mathrm{a}, 129 \mathrm{a}, \mathrm{b} \mathrm{StGB}$, derive in their current form directly from EU Council Framework Decision 2008/919 and also concur with the more recent Directive 2017/541. ${ }^{47}$ Petzsche $(2012)^{48}$ provides a detailed account of the intricate interrelation of EU legislation and German criminal law, pointing to a 'strong influence' of European law on 'anti-terrorism law in Germany'49, often widening offences and criminal charges beyond European legislation and 'featuring the same wording - apart from negligible difference' ${ }^{50}$.

\section{Ratio legis and application of 'state-threatening act of violence' in the context of jihadism in Syria and Iraq}

According to German criminal law an in concurrence with EU legislation, a state-threatening act of violence is marked inter alia by the intention to commit homicide or murder, or hostage taking or abduction for ransom in order to weaken or threaten state structures ( $\$ 89 \mathrm{a}$ (1) StGB). This applies particularly where the perpetrator has provided or received training in the handling of weapons or possesses or keeps weapons or parts that may be used for the construction of weaponry ( $\$ 89 \mathrm{a}$ (2) StGB). Introduced in 2009, the norm constitutes an essential part of the terrorism clauses in German criminal law. ${ }^{51}$ The interconnection of the act of premeditated killing and the state-focused orientation of this act is an essential part-it connects physical and symbolic violence. In June 2015, a supplementary paragraph (2a) to that norm was enacted, which extends criminal liability to travelling abroad with the intent of preparing an act of statethreatening violence and/or with the intent of giving or receiving training in the handling of dangerous weapons that are subsequently used to commit the eventual attack on the state. The addition specifically mentions the criminal liability of travelling abroad to undergo or give paramilitary training in camps, or to provide instruction to, or receive instruction from a third person in the use of weapons for terrorist purposes. In essence, the law addresses a contingent space by forwarding legal action against anticipated criminal conduct (Tatvorverlagerung) that also derives from EU legislation and is controversially debated by legal practitioners. ${ }^{52}$ Case 2

\footnotetext{
47 (N 3).

${ }^{48}$ Anneke Petzsche, ‘The European Influence on German Anti-Terrorism Law' (2012) 13 Ger. Law J. 1056.

${ }^{49}$ Ibid, 1065.

${ }^{50}$ Ibid, 1060.

${ }^{51}$ Bundesgesetzblatt 2009, I (49), 03. August 2009, 2437.

52 Bundesgesetzblatt 2015, I (23), 20. June 2015, 926. Puschke (n 10); Puschke and Rienhoff (n 10) 243, Erling J Husabø, 'Die Kriminalisierung von terroristischen Straftaten und deren Vorbereitung in den nordischen Ländern - eine kritische Betrachtung’ (2013) 124 ZfS.
} 
ACCEPTED MANUSCRIPT, New European Journal of Criminal Law, SAGE (Oct, 20, 2021).

Volume: 12 issue: 4,page(s): 552-574 https://doi.org/10.1177/20322844211060227,

Article first published online: November 11, 2021; Issue published: December 1, 2021

below constitutes the first trial on charges under this addition to $\S 89 \mathrm{a}$ StGB, just a few months after its enactment.

\section{(a) Presentation of cases}

Case $1^{53}$ was tried by the BGH in October 2015 on the appeal of the GBA in response to the acquittal of the accused in the previous instance. The Federal Court rejected the appeal and reiterated the previous court's ruling. The case details are as follows. In early 2014, the female defendant L. (civil status: divorced) migrated to Syria with her two minor children to become the second wife to K., a fighter of the Jabhat al-Nusra (JAN) militia whose political aims she sympathized with. ${ }^{54}$ Her migration was facilitated from Syria by M., K's first wife, with whom L. had been in contact throughout the process. During her sojourn in Syria, L. received training in the handling of a Kalashnikov (AK47) and a machine gun. Her family further had hand grenades at their disposal that were destined for self-defence purposes in case of confrontations with rival militias or the Syrian Army. According to her statement, the defendant had been prepared to use these weapons for self-defence and to kill potential assailants. As a result of continued fighting, the family was compelled to move several times so as to remain behind moving frontlines and evade armed confrontations. On May 23, 2014, the defendant returned to Germany as, in her assessment, the situation was getting too dangerous for herself and her children. In 2015, L. was charged by the GBA on the grounds of §235 (2) StGB (parental child abduction) as she had taken the children against the will of their father, and $\$ 89 \mathrm{a}$. The first instance court convicted the accused on charges of $\$ 235$ (2) StGB and sentenced her to eighteen months' probation; the charges on grounds of $\S 89$ a StGB, however, were rejected for lack of evidence.

Case $2^{55}$ was decided by the BGH in April 2017 on the appeal of the defendant following his indictment on charges of $\S 89 \mathrm{a}(2 \mathrm{a}) \mathrm{StGB}$. The Federal Court rejected the appeal and ruled that the norm had been applied correctly. The details of this case are as follows. In 2015 the defendant attempted to migrate to Syria on two occasions, where he planned to join the armed struggle of an Islamist organization, presumably JAN or an associated branch. The defendant intended to get himself trained in the use of firearms and explosives to support the fight against the Assad regime 'in the name of jihad' ${ }^{56}$ and defeat the Syrian state. On his first attempt to migrate to Syria in June 2015, he failed to cross the Turkish-Syrian border and returned to Germany within two days. On his second attempt in October 2015, he was arrested at the airport. The police secured his one-way ticket to Adana, Turkey, outdoor clothing, two cell phones and

\footnotetext{
${ }^{53}$ BGH, 27. October 2015 3StR 218/15.

${ }^{54}$ Letter attributed for ease of reference and at random by the authors.

${ }^{55}$ BGH, 06. April 20173 StR 326/16.

${ }^{56} \mathrm{Ibid}, 3$.
} 
270 EUR in cash. The court of first instance declared the accused guilty as charged and sentenced him to two and a half years in prison.

\section{(a) Construction of the defendants' subject positions under the charges}

The courts' argumentation in Case 2 emphasizes that, even though his migration to Syria failed, the defendant travelled abroad with the intent to undergo military training and join the armed struggle, which would have enabled him to commit acts against the Syrian state as charged. The court considered evidence on the imminence of his engagement as sufficient. In regard to the legal assessment of state-threatening violence, the argumentation specifies that a threat to the state emerged from the defendant's intended participation in armed conflict, in particular inasmuch as this would have included the projected killing of soldiers of the Syrian Army ${ }^{57}$. In his defence, the appellant argued that regardless of the participation of third-party individuals, the conflict in Syria was ongoing and the Syrian state was already substantially impaired in certain areas in terms of internal security and the local population's trust in state protection. To this the BGH responded that these contextual arguments neither held nor served to benefit the appellant: 'On the contrary, the substantial destabilization of the security situation observable in Syria is one of the reasons that even the participation of individuals - even in isolated instances - of armed confrontations may suffice to severely impact the capacity of the Syrian state to defend itself against such interferences because, in the end, the outcome of a series offurther-destabilizing acts might be the collapse of the state system at any time, ${ }^{58}$.

In Case 1, on the other hand, the BGH emphasized that a civilian sojourning with a member of a foreign terrorist organization in a war zone could not be considered to be preparing a statethreatening act of violence even if he or she was instructed in the use of firearms for the purpose of the self-protection and protection of his or her family ${ }^{59}$. On this particular issue, in their appeal, the Public Prosecutor contested the previous court's argument that 'it was doubtful too whether a willingness to use weapons or the killing of a number of government troops in potential though in no way concretized attacks was at all designed and apt to threaten the existence and security of Syria ${ }^{60}$, by arguing that, beyond any doubt, the killing of members of the Syrian Army was apt to compromise the security of the Syrian state. The BGH, however, reiterated the previous court's argument, suggesting that 'not every act of violence against the life and limb of combatants in an armed conflict is apt per se and without consideration of further circumstances to fulfil the state protection clause ${ }^{61}$.

In addition to the necessity of intent and purposivity to commit violent acts, the organization of violence matters in the consideration of $\S 89 \mathrm{a}$ StGB. The addition of that norm to German

\footnotetext{
${ }^{57}$ Ibid, 5.

58 Ibid, 11.

59 (N 48) 1.

${ }^{60}$ Ibid, 6.

${ }^{61}$ Ibid, 9.
} 
criminal law, so the court argued, aimed at 'allowing a more effective prosecution of (individual) perpetrators who are not incorporated in organizational structures... particularly in view of the increasing decentralization particularly of organizational structures of militant Islamism ${ }^{62}$. 'The ratio legis of the norm thus aims at the prosecution of individual terrorists' ${ }^{63}$.

\section{(b) Impact of individual acts on state security in the context of civil war}

From the juridical perspective, the argumentation does not require further discussion since the decisions underline how, for Case 1, the behaviour and intentions of the defendant while in Syria do not fulfil the requirements of the norm, whereas Case 2 highlights the essential behavioural features and intent that the norm has in view — as intended by EU legislation. From a socio-legal perspective, however, three intertwined aspects of the courts' and prosecution's argumentation are of interest and require further debate, as they provide the basis for the gendering of both crime and defendants. The three aspects are: firstly, the assessment of the defendants' agency with regard to the danger they posed to the Syrian state, which strongly relies on the construction and semantics of active or passive subjects; secondly, the temporality of potential actions implied by notions of imminence or improbability; and, thirdly, the referral of actions to the public or private space. When disentangled, so we argue, these dimensions allow us to understand the way in which legal subjects are constructed in the semantics of the respective criminal law or, rather, in its application.

The delict of preparations for 'state-threatening act of violence' includes elements of projection, intention and premeditation - it thus concurs with the temporal embedding of agency defined above. Its object is 'the state', that is, the state's representatives and its (immaterial) and sovereign symbols such as, for example, the monopoly of power. The agent perpetrating the threat is thus active and resolved and thereby holds both physical and symbolic power by which the degree of danger that he or she poses is defined. In the courts' argumentation, the negotiation of the defendants' destabilizing potential towards the Syrian state is based on access to and intent to use weapons of war as well as the objects of potential violent acts. While one defendant had already received weapons training, the other had not, but intended to acquire it. While the former argued that the object of violence was indiscriminate (state or non-state) and that her actions were dependent on the emergence of a life-threatening situation for her family, the intended object of potential violent acts by the latter, according to his resolve, would have been primarily representatives of the Syrian state. Against these contexts of intent and resolve, the potential killing of non-state fighters does not receive particular consideration from the courtthe killing of Syrian soldiers, however, and the context of an ongoing civil war towards which the defendants positioned themselves intentionally and deliberately are assessed differently in each case. In Case 1, the defendant's resolve to use weapons is legitimized by self-defence against attacks by the Syrian army ${ }^{64}$, invoking her duty as a mother and carer to her family, yet,

\footnotetext{
${ }^{62}$ Ibid, $10-11$.

${ }^{63}$ Ibid, 11.

64 (N 48) 9.
} 
the likelihood of an incident occurring is expressed in the conditional tense, since she-or, rather, her clan-made efforts to withdraw from frontlines, and a confrontation with Syrian soldiers was considered by the court to be somewhat 'inconcrete' ${ }^{\prime 65}$. In the case of the female defendant, the court of first instance suggested that it was unlikely that the 'killing of a number of government troops in potential ... attacks was ... apt to threaten the existence and the security ${ }^{66}$ of the Syrian state. In the case of the male defendant, the court of appeal expressly referred to the context of ongoing war and highlighted that 'even the participation of individuals — even in isolated instances — of armed confrontations ${ }^{967}$ might impact state security and, within this context, the outcome of a series of such events might 'be the collapse of the state system at any time ${ }^{68}$.

The content analysis of the documents shows that the interpretation of the norm implies different social categories for male and female defendants that possess their own semantic framing and temporal description of agency. Where the male defendant is described as an active agent, a 'future member', future trainee/paramilitary, 'planning to use the skills he is about to acquire', and both his objective in migrating and his political intent are presented as if there were an almost undisputed likelihood of their being accomplished, the female defendant is presented as a passive civilian, 'sympathizing with', 'wife to', 'mother', who 'accepted the offer' to migrate to Syria, marry K. and join the clan. Her possible involvement in violent action is placed in the realm of the improbable, expressed by the conditional tense. These semantic frames finally also reflect the last of the three issues of concern: the structure of the public and the private sphere. As the BGH emphasizes, §89a was formulated to enable the preventative prosecution of the 'individual terrorist fighter' in the 'militant Islamist area' by taking into account their often 'loose connection to formal organizational structures' ${ }^{69}$. These specifications acknowledge male opportunities, roles and resources for participation in organized violence specifically, as they are visible and recognized in the public sphere. In regard to the binary 'individual-state' relation specified in the norm and its focus on state security, female engagement in violent structures, which empirically differs from that of male supporters, cannot be recognized and is subsequently relegated to the private sphere. ${ }^{70}$ As a consequence, in the present case, the defendant's decision to migrate to Syria and engage with the civilian compound of the JAN is depoliticized, her agency consists neither in physical nor symbolic power. Inasmuch as it is recognized by the court, it is confined to her roles as a mother and spouse. Consequently, her decision to return to Germany after a few months for security reasons and fear for her life and that of her children, is aligned with her maternal role.

\footnotetext{
${ }^{65}$ Ibid, 6.

${ }^{66}$ Ibid.

67 (N 50) 11.

${ }^{68}$ Ibid, 2.

69 (N 48) 11.

${ }^{70}$ Loken and Zelenz (n 5).
} 
As the BGH stated, "not every act of violence against the life and limb of combatants in an armed conflict is apt ... to fulfil the state protection clause ${ }^{\text {, }}$, yet, there are inherent assumptions and normative premises encased in $\S 89$ a that may privilege the adaptation of the norm to male over female participation in violence.

\section{Ratio legis and application of 'membership of' and 'support for' terrorist organizations in the context of jihadist organizations in Syria and Iraq}

The analysis of Cases 3 and 4 is framed by the criminal legal norms of $\S 129 a$ and b StGB. Paragraph 129a StGB regulates the criminal liability of the 'formation of', 'membership of' and 'support for a terrorist organization'. It specifies the elements of violence that fall within the norm, including, among others, murder, homicide, crimes against humanity, grave physical and psychological damage to others, crimes relating to the control of weapons of war and breaches against the handling of classified firearms. Of particular interest to the analysis here are $\$ 129 \mathrm{a}$ (2) and (5) StGB, inasmuch as paragraph 2 criminalizes not only 'first degree' perpetratorship, that is, the carrying out of acts of violence, but includes 'second degree' perpetratorship, that is culpability through mere association (membership) with an organization that commits the said crimes. This norm may be applied in cases where the scope of the organization's crimes aims at seriously intimidating a population, to unduly compel (or threaten to do so) an government, or to destabilize or defeat the political, constitutional, economic or social foundations of a state. All of these elements apply to the organizational behaviour of ISIS and Junud-al-Sham (JAS) in Syria and Iraq. Paragraph 5 of that law details the penalties for 'acts of support' which include the recruitment of further members and supporters. Paragraph 129b StGB extends the applicability of $\S 129$ a to cases of foreign criminal and terrorist organizations insofar as the activities of the organization either extend to EU territory, or as the perpetrator or victim of their crimes is a German national, or if the perpetrator or victim is resident on German home territory at the time of the crime. The empirical cases presented highlight questions in regard to the application of the norms in contexts where the involvement of the accused with the above organizations is questioned. In the subsequent discussion of this section, our argument focuses on the limitations of the law in regard to the intertwined relation of ISIS as a terrorist organization and the Caliphate as its politico-social project, on the one hand, and the specific focus of the law on forms of male engagement in terrorism.

\section{(a) Organizational and agency dimensions of 'support'}

Case $3^{72}$ (BGH StB 18/17) concerns a complaint by the Public Prosecutor against the OLG's refusal to open main proceedings in the case of the two female defendants on charges of $\$ 129 \mathrm{a}$ (5) StGB. The two defendants S. (female friend of P.) and O. (sister to P.) were accused of

\footnotetext{
71 (N 48) 9.

${ }^{72}$ BGH, 14. December 2017 StB 18/17
} 
having jointly organized a collection of funds for the convicted P. (member of JAS) as agreed with P. by phone on November 17, 2013. At that time, P. was staying in Syria and active with JAS. In December 2013, S. handed €275 to O. In January 2014, O. flew to Syria to deliver the money to her brother in person. In addition, she also brought him clothing, foodstuffs and sanitary products for personal use. Both defendants were aware of P.'s enrolment with JAS and shared the ideology of jihad which they intended to support through their proxy contribution to P. They explicitly approved of the redistribution of the supplies to and their use by third parties.

In its decision on the case, the BGH reaffirmed the OLG's decision not to open main proceedings as the evidence provided by the Public Prosecutor was insufficient to make a successful trial and the conviction of the defendants likely. One of the main arguments in the OLG's decision was based on the issue that - from the evidence provided - the financial and other resources collected by the defendants had only benefited P. personally and that there was no evidence of a benefit to JAS. Although contributing to a member's well-being might constitute an indirect benefit for the organization, so the court argued, insofar as it might enable, for example, an improved performance by the member, or increase his capacities and willingness to contribute to the organization's aims, this effect would still need to be proven in an objectifiable and path-dependent manner. Such proof would be constituted, for example, if the funds had been used for the procurement of ammunition or any other functional equipment within the organization. The court further outlined the negligibility of the funds in terms of financial support by pointing to the fact that, upon his return to Germany, P. was in possession of some $€ 1500$ in cash. This, so the OLG concluded, gave reason to believe that P. might not even have used the funds provided by the defendants. As to the other items, the court concluded that these could be considered basic livelihood support among relatives despite the rather unusual means by which they were transferred ${ }^{73}$. The court acknowledged the potentially positive effect of the donation on P.'s well-being and his performance within JAS, but underlined that there was, however, no evidence of an objectifiable use for the benefit of the $\operatorname{organization}^{74}$.

In its statement, the BGH focused on clarifying the different dimensions attached to charges of 'support' in cases of civilians' engagement with affirmed members of a terrorist organization. It explained, firstly, that the notion of 'support' as per StGB included "any action of a nonmember that strengthens the internal coherence of an organization or criminal association" 75 and that 'facilitates its carrying out of criminal acts or positively impacts its space of action and objectives and, in so doing, makes it more dangerous "76. Secondly, with regard to 'objectivity', the BGH emphasized that 'it is both necessary and sufficient that the act of support is in and by itself objectively useful for the organization and produces some kind of benefit for it ... it is not necessary to establish an objectifiable benefit for the organization that follows from the

\footnotetext{
${ }^{73}$ Ibid, 4.

${ }^{74}$ Ibid, 5 para 8.

75 Ibid, 6 para 14.

${ }^{76}$ Ibid.
} 


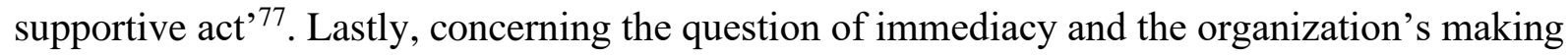
use of support provided, 'it is sufficient to establish that the supportive act produces some kind of advantage for the organization. An activity which, in substance, constitutes an aid to the member's participation in the criminal organization, in principle also constitutes a sufficient benefit to the organization,78. 'This,' so the argument continues, 'applies in all cases where the perpetrator encourages a member to carry out a task which has been assigned to him by the organization, or enhances the member's determination to commit offences that serve the purpose of the terrorist group or that are in line with the group's activities, ${ }^{79}$.

Further the BGH argued that the prosecution provided sufficient evidence neither of the transfer of funds or goods for organizational purposes nor on their relevance to P.'s engagement in the organization ${ }^{80}$. In conclusion, therefore, 'the defendants neither supported JAS by promoting their activities and terrorist objectives nor by aiding and abetting P.'s activities as a member' ${ }^{81}$.

\section{(b) Organizational and agency dimensions of 'membership'}

In Case $4^{82}$, the GBA submitted a request for an arrest warrant, within the scope of their investigation of the defendant on charges of membership of a foreign terrorist organization and membership-related activities ( $\$ 129 \mathrm{a}, \mathrm{b}$ StGB). The defendant $\mathrm{H}$. and her spouse B. had decided to join ISIS in 2016. As agreed with a middleman, they flew to Turkey in March 2016 from where a smuggler helped them move to Syria. Subsequently they lived in ISIS-controlled territory, initially in Syria, later on in Iraq, where B. worked as a nurse. Based on B.'s work, the couple received a monthly allocation of US $\$ 100$ from ISIS. In November 2016 the defendant gave birth to a child. From late 2016 on the couple were compelled to move several times due to the deteriorating security situation in the region. In August 2017 the defendant and her spouse entered Peshmerga-controlled territory with the help of a smuggler and were arrested. At that time, H. was pregnant again. During her sojourn on ISIS-held territory, the defendant was in charge of household chores and managing all necessary tasks for their living such as, for example, grocery shopping.

In its appeal to the BGH, the Public Prosecutor argued the defendant's membership-related engagement with ISIS as follows. Firstly, by travelling to ISIS territory, the defendant 'submitted herself to the control of the organization' and by her presence supported 'the expansion of its human resources', which also exerted a 'pull-effect on like-minded people in Europe $^{83}$. Thanks to her appearance, being a foreigner and Western European, and her position within the organization, the defendant could be identified as a member of the organization's

\footnotetext{
${ }^{77}$ Ibid, 7 para 14.

${ }^{78}$ Ibid, 8 para 16.

${ }^{79}$ Ibid.

${ }^{80}$ Ibid, 9 para 19.

${ }^{81}$ Ibid, 8 para 17.

${ }^{82}$ BGH, 22. March 2017 32/17.

${ }^{83}$ Ibid, 4 para 8.
} 
inner circle and, therefore, as a supporter ${ }^{84}$. In contrast to the local population's forced acceptance of the ISIS regime, her presence was to be construed as the outcome of an intentional and informed accession to ISIS ${ }^{85}$. Secondly, in the narrative of the Caliphate, so the prosecution's argument continued, women's roles were central given their focus on household chores and, in the case of married women, on giving birth and educating their children according to ISIS ideology. In performing these tasks and duties while her spouse worked in an ISISadministrated hospital, the defendant 'breathed life into the idea of a Caliphate' ${ }^{86}$. She accepted and complied with that role as expected by the organization and, consequently, contributed to its objectives in an active manner. Furthermore, by giving birth to her first child on ISIS territory and through her renewed pregnancy there, she made an 'active, membership-related contribution', aiming at increasing the organization's 'state constituency' ${ }^{87}$. The organization's acknowledgement of her continued presence and participation in local life was further evidenced, so the prosecution's argument ran, by the payment of monthly family allowances ${ }^{88}$.

The BGH reaffirmed the previous court's rejection of an arrest warrant and substantiated its response by clarifying the legal definitions of 'membership' and 'criminal and terrorist organization' as relevant to $\S 129 \mathrm{a}$ StGB in the context of ISIS and the Caliphate as the organization's political project.

As per StGB, the term 'terrorist organisation' refers to a 'longer-term association' of 'at least three people' who subjugate their individual will to a collective one in the pursuit of a 'common objective ${ }^{89}$ and who share a 'collective understanding of their association' ${ }^{90}$. Membershiprelated activities require some kind of 'formal integration' of the perpetrator into the organization ${ }^{91}$ - the fulfilment of supporting activities alone does not confer membership status. Finally, membership refers to a 'relation of mutual consent and recognition'92, that is, it cannot be forced upon the organization by a non-member. Additions to this definition are provided by the European Council Framework Decision (CFD) on the fight against organized crime ${ }^{93}$ which broadens this hierarchical and quasi-formal understanding of organization so as to correspond to the evolution of the structures of organized crime. In particular, the CFD details that neither specification of members' roles nor continued membership nor a specific organizational structure is a necessary requirement to define a terrorist organization. In addition to StGB's focus on small organizational units with a consensual ideological base, the CFD also includes organizations that are hierarchical, interest-based and that operate without a collective identity. In every other respect, the CFD concurs with the definition of StGB.

\footnotetext{
${ }^{84}$ Ibid, 5 para 11.

${ }^{85}$ Ibid.

${ }^{86}$ Ibid, 4 para 8.

${ }^{87}$ Ibid, 5 para 9.

${ }^{88}$ Ibid, 5 para 10.

${ }^{89}$ Ibid, 7 para 17.

${ }^{90}$ Ibid.

${ }^{91}$ Ibid, para 18.

92 Ibid, 8 para 19.

93 (N 4).
} 
Against the background of these definitions, the $\mathrm{BGH}$ concluded that, in regard to the defendant's engagement in Syria and Iraq, she could neither be considered a member of a terrorist organization nor as engaging in membership-related activities as suggested by the prosecution. The decision detailed that 'everyday life on ISIS territory cannot be equated with the organization itself ${ }^{94}$ and as such, sojourning on the territory of the organization did not make any person a member of the organization. By consequence, 'the everyday life of such persons living in the "Caliphate" does not constitute a membership-related activity" 95 , this particularly applies to women who decided to live with a member of the organization and gave birth to a child emerging from that relationship (ibid.). As far as the court was concerned, direct support by the defendant to ISIS delivering so much as an indirect advantage in regard to the fulfilment of its organizational objectives could not be recognized ${ }^{96}$. As for her assisting her spouse in membership-related activities by enabling his engagement as a nurse in an ISIScontrolled hospital, the court noted that there was evidence of neither physical nor psychological support from her. More specifically, in terms of physical support, her daily tasks were limited to mere housekeeping and grocery shopping and, in terms of psychological instigation, there was no indication in the indictment that the defendant had influenced her spouse in his decision to join ISIS ${ }^{97}$. Further, based on the lack of evidence in regard to her 'representative functions' as an expatriate supporter of ISIS the court neither followed the prosecution's argument that her foreignness and association with members of the organization was sufficient to create the impression of membership nor did it recognize any indication of representative functions or other tasks delegated by the organization ${ }^{98}$.

In the course of further investigations into Case 4, information became public that two years prior to her most recent sojourn in Syria, the defendant H. had already been to ISIS-controlled territories with her previous spouse. ${ }^{99}$ After he died in combat, she returned to Germany, contacted her second spouse online and returned to the Caliphate with him. According to the prosecution, her knowledge of the local ISIS structures also helped situate her spouse as a nurse. ${ }^{100}$ Consequently, H. played a decisive role as the initiator and decision-maker as regards the migration to Syria and did not merely follow.

\section{Discussion}

Against the background of the four presented cases, the central questions that framed our argument need to be addressed as follows.

\footnotetext{
${ }^{94}$ Ibid, 9 para 23.

95 Ibid, para 24.

${ }^{96}$ Ibid, para. 24.

${ }^{97}$ Ibid, 14 para 35.

${ }^{98}$ Ibid, 10-11, para 27.

${ }^{99}$ BGH, 26. June 2018 StB10/18

${ }^{100}$ Ibid, 9 para 17.
} 
ACCEPTED MANUSCRIPT, New European Journal of Criminal Law, SAGE (Oct, 20, 2021).

Volume: 12 issue: 4,page(s): 552-574 https://doi.org/10.1177/20322844211060227,

Article first published online: November 11, 2021; Issue published: December 1, 2021

Firstly, in all four cases, the socio-relational context of the defendants' political engagement has been made transparent through their orientation towards the organizational objectives of ISIS and JAS. In regard to analysis of agency, we suggested in the earlier section (p.5) to differentiate along phases and dimensions of engagement. Phases may be differentiated into 'preparatory' and 'accomplished', whereas dimensions of engagement may extend from psychological through social, economic and other actions contributing to organizational effectiveness. Table 2 presents these dimensions with regard to preparatory and accomplished actions in view of their migration and (self-)deployment to ISIS territories and juxtaposes this to the courts' assessments. When looked at from this perspective, in at least three cases, the defendants accomplished acts of support and engaged with jihadist organizations: by successfully migrating to ISIS-territories (cases 1, 3 and 4) and by implementing organizational objectives by strengthening the jihadi community in Syria and Iraq (cases 1 and 4), service provision $(1,4)$ and logistical support $(3,4)$. 
ACCEPTED MANUSCRIPT, New European Journal of Criminal Law, SAGE (Oct, 20, 2021).

Volume: 12 issue: 4,page(s): 552-574 https://doi.org/10.1177/20322844211060227, Article first published online: November 11, 2021; Issue published: December 1, 2021

Table 2. Juxtaposition of accomplished actions and BGH assessments of defendants

\begin{tabular}{|c|c|c|c|c|}
\hline & \multicolumn{2}{|c|}{$\begin{array}{l}\text { 'State-threatening act of violence' } \\
\text { (\$89a StGB) }\end{array}$} & \multicolumn{2}{|c|}{$\begin{array}{l}\text { 'Membership of/support for terrorist } \\
\text { organization' (\$129a, b StGB) }\end{array}$} \\
\hline Cases/Gender & Case 1 - Female & Case 2-Male & $\begin{array}{l}\text { Case } 3-\text { Two } \\
\text { females (relative } \\
\text { to one male) }\end{array}$ & $\begin{array}{l}\text { Case } 4-\text { Female } \\
\text { (relative to one male) }\end{array}$ \\
\hline $\begin{array}{l}\text { Actions } \\
\text { accomplished }\end{array}$ & $\begin{array}{l}\text { Migration } \\
\text { accomplished (five } \\
\text { months stay); } \\
\text { Provided } \\
\text { humanitarian } \\
\text { support (?); } \\
\text { Sympathizer with } \\
\text { ISIS/Caliphate; } \\
\text { Marries JAN/AQ } \\
\text { fighter; training; } \\
\text { Weapons } \\
\text { possession of arms } \\
\text { and storage of } \\
\text { explosive devices; }\end{array}$ & $\begin{array}{l}\text { Migration failed twice; } \\
\text { Potential member of } \\
\text { JAN in SYR } \\
\text { Potential trainee in } \\
\text { armed combat; } \\
\text { Potential perpetrator of } \\
\text { state-threatening } \\
\text { violence; } \\
\text { Planned to procure } \\
\text { technical parts for the } \\
\text { construction of } \\
\text { explosive devices; }\end{array}$ & $\begin{array}{l}\text { Collection of in- } \\
\text { kind and } \\
\text { financial } \\
\text { donations for } \\
\text { JAS member and } \\
\text { the organization; } \\
\text { Travel to SYR } \\
\text { for handover of } \\
\text { items. }\end{array}$ & $\begin{array}{l}\text { Migration } \\
\text { accomplished } \\
\text { months stay); } \\
\text { Organization of } \\
\text { everyday life to support } \\
\text { spouse's work; } \\
\text { Housework; Presence } \\
\text { at execution(s); } \\
\text { Access to higher } \\
\text { command ranks of ISIS }\end{array}$ \\
\hline $\begin{array}{l}\text { Assessment } \\
\text { of the court }\end{array}$ & $\begin{array}{l}\text { Status of civilian in } \\
\text { SYR; } \\
\text { Defensive use of } \\
\text { weapons; } \\
\text { No threat to SYR } \\
\text { state. }\end{array}$ & $\begin{array}{l}\text { Status of future member } \\
\text { resolved to carry out } \\
\text { acts of violence; } \\
\text { In-kind and financial } \\
\text { resources relevant } \\
(€ 271 \text { telephone, } \\
\text { outdoor clothing); } \\
\text { Planned offensive use } \\
\text { of weapons; } \\
\text { Threat to SYR state. }\end{array}$ & $\begin{array}{l}\text { Insufficient } \\
\text { evidence; } \\
\text { In-kind and } \\
\text { financial } \\
\text { resources } \\
\text { irrelevant ( } € 275 \text {, } \\
\text { clothing, hygiene } \\
\text { articles); } \\
\text { Supportive } \\
\text { activity irrelevant } \\
\text { to supported } \\
\text { member and } \\
\text { organization as } \\
\text { money not spent, } \\
\text { goods not } \\
\text { forwarded. }\end{array}$ & $\begin{array}{l}\text { Insufficient evidence; } \\
\text { Status of civilian in } \\
\text { SYR; } \\
\text { Accompanying role as } \\
\text { mother and spouse; } \\
\text { Not a member and no } \\
\text { membership-related } \\
\text { activities. }\end{array}$ \\
\hline
\end{tabular}

Secondly, in regard to the question of where and how women's support to and membership in a terrorist organization in Syria and Iraq can be established, our argument has pointed out that the definitions of support and membership of criminal law do focus on specific actions and specific organizational processes respectively. In this specificity, they include predominantly male areas of engagement and prioritize a formalized understanding of organizational membership and leave out areas of female engagement and informal group structures. Or, in other words, by limiting the focus to the preparation and implementation of symbolic violence, they exclude, to a large part, its enabling structures and processes. Particularly when looked at 
from the socio-relational perspective of agency as we have introduced it, this shuts off the context factors of symbolic violence as well.

Thirdly, the question of whether or not the mere presence of (foreign Western) women on ISIS territories constitutes an act of support or even membership of the organization has been denied from a perspective of criminal law. Our empirical data collected from court hearings and accounts of returning male and female jihadists provide a more nuanced picture. From a sociolegal perspective, the migration to ISIS-controlled territories, in particular for women and girls, could not be accomplished without the explicit approval of administrative or military instances on the ground. This means that, at the earliest before travelling (from EU territories) and at the latest upon arrival at the Turkish-Syrian border, female migrants heading to these territories had to submit administratively (handing out passports) and physically (moving to appointed safehouses) to the administration of ISIS.

Fourthly, our argument started out with the question whether or not the political nature of women's engagement with jihadist organizations was recognized by the courts. Here, our analysis demonstrated that, to the extent that arguments were made public, this was not the case. The comparison of Cases 3 and 4, for example, highlights the empirical differences in the application of $\S 129 \mathrm{a}$ and $\mathrm{b}$ StGB to male and female engagement in the context of ISIS. Both cases share commonalities and figure constellations of female engagement and supportive acts and, in both cases, the assessment leads the court to conclude that these cannot be considered relevant to the organizations. With respect to the organizational dimension of their engagement, in both cases, the court assessed the female agents to be disconnected from any (formal) organizational context. As regards the social dimension of support and the relational constellation within which the defendants found themselves in Syria, in both cases, their presence and engagement was referred to as taking place in private space. And, lastly, the contributions provided by the female agents were evaluated as insignificant in both cases.

\section{Conclusion}

The recontextualization of indictments and juridical argumentations from a gender-focused sociological perspective offers the possibility of discussing the challenges and opportunities that are attached to the national juridical processing of a gender-specific transnational mobilization of civilians to ISIS. As stated earlier on, this work is conducted on the basis of the sociological understanding that the epistemics of criminal law and legal decisions are embedded in societal dynamics and social processes. Our discussion thus does not question or evaluate the technical correctness of the analysed decisions. Rather, it focuses, firstly, on where and how we can establish gender bias in the application of criminal legal norms with regard to women's engagement in transnational extremist violence and, secondly, on the processes by which women are depoliticized as political agents. A critical discussion of the normative and sociolegal scope of terrorism and security laws, in our view, is essential to strengthening legal and social accountability and increasing the performance of mitigating, preventative and 
rehabilitation measures. To conclude our argument, we therefore propose to systematize the following issues that, to us, seem topical to gender-sensitive socio-legal research on the subject.

EU and concurrent German criminal legal norms on terrorism are formulated primarily in response to male engagement and from a state-centric, territorial perspective. They thus carry specifications derived from the legal ontology of the organized violence and terror against which they were developed. In the context of ISIS, the boundaries between the core and the periphery, between, on the one side, officials, administrators, law enforcement officers and others and, on the other side, members of the supportive self-proclaimed transnational active constituency of the Caliphate and their social networks are rather fluid. The analysed cases illustrate the difficulty of situating and assessing the relevance of the defendants' actions in relation to the core organization of ISIS, particularly as far as female support is concerned. With respect to male engagement, the norms reproduce, idem per idem, that which they encapsulate and apply it in a rather self-evident form - even to the point, with regard to Case 2, where the projected contribution to the organization is presumed to succeed and tried accordingly.

In the discussion of the cases and their recontextualization, we argue that two underlying issues contribute to gender-biased political and legal perspectives on the organization of violence. These are, firstly, the historically state-centric definition and location of terrorism, which materializes, inter alia, in the differentiation of 'home' and 'foreign' territory as well as in the differentiation between actions undertaken in public and private spaces. In the assessment of supportive acts, membership, etc., these assumptions are likely to continuously limit the assessment of individual and collective contributions to violence as organizational structures evolve and extend not only beyond national borders, but also into the digital world as neither national nor foreign, neither solely public nor entirely private. The second problem revolves around the determination and acknowledgement of agency and agentic orientation in the defendants by the organization, as well as by the judicial institutions. The cases illustrate the extent to which the motivation of the defendants' actions played a different role in the two normative settings, having a more important one as concerns $§ 89 \mathrm{a}$ StGB and a less important one as concerns $\S 129 \mathrm{a}$ and b StGB. In both legal contexts, however, the courts' assessments of the relevance of the defendants to dynamics of conflict and violence reproduced gender-specific assumptions that decontextualized the political dimensions particularly of the female defendants' engagement. As the discussion in the previous section illustrates, the organizational acknowledgement of women travelling to the Caliphate is empirically established and holds organizational benefits, otherwise women would be left to their own devices when entering the territories without a male counterpart. The entry and exit rules to ISIS-controlled territories, the administrative procedures that new arrivals, men and women, had to go through, cannot be left out in the establishment of evidence on mutual acknowledgement and recognition. It is thus difficult to depoliticize the time spent by expatriate women in the Caliphate as 'mere presence' as was done in Case 4. At the same time, the gendered nature of women's and men's statuses also includes the precarious shifts between positions of relative social power and powerlessness that come, as far as women are concerned, in regard to their social status (married vs. unmarried, 
ACCEPTED MANUSCRIPT, New European Journal of Criminal Law, SAGE (Oct, 20, 2021).

Volume: 12 issue: 4,page(s): 552-574 https://doi.org/10.1177/20322844211060227,

Article first published online: November 11, 2021; Issue published: December 1, 2021

divorced or widowed), and, as far as men and women are concerned, in regard to their relative (in)security as regards the impossibility of opposition, and thus, ultimately, free will.

While these problems emerge from the discussion of gender biases in criminal legal norms, we agree that they may not be solved by criminal law alone. Similarly, the security focus of EU and domestic terrorism policies frame the understanding of a potentially much wider problem of new conflict dynamics. In order to productively grasp the political, social and criminal-law scope of transnational mobilization to violence, however, the critical discussion to which this paper contributes, needs to continue, focusing on empirical developments and ways in which violent groups and terrorist organizations are likely to engage and operate in the future. 